\title{
Organizational Culture and Work Stress among Bank Employees
}

\author{
Sarath, $\mathrm{P}^{1 *}$, Manikandan, $\mathrm{K}^{2}{ }^{2}$
}

\section{ABSTRACT}

Banking sector is one of the most powerful financial management agencies which have a major role in the economic growth of India. Each bank has its own culture, as every organization different in their culture. Organizational Culture includes everything that influences an employee in an organization. This may reflect in their stress levels, which may in turn reflect in the individual productivity as well as the organizational. In the literature, there were different studies of organizational culture and work stress among bank employees, but very few studies which tried to explore the relation between organizational culture and work stress in India especially in the state of Kerala. This study was intended to find the nature of organizational culture and work stress of banks employees of northern Kerala.

Keywords: Bank employees, Kerala, Organizational culture, Work stress.

Everyone is earning money to meet their daily expenses and to save money for future expenses. For keeping, managing and distributing the money for the needy people, the banking system has emerged all over the world. Banking in India originated in the 18th century. By this day, it has gone through different changes and transitions and became one of the important financial sectors in the country. The banks of India are working on the basis of definite instructions which are passed in the form of various acts and regulations. Currently, banks in India are classified into scheduled commercial banks and scheduled cooperative banks. This classification is formed on the basis of nature of ownership or nature of operation. Scheduled commercial banks include all the nationalized banks and private banks. Scheduled Co-operative Banks includes State Cooperative Banks and Urban Cooperative Banks.

Culture includes everything that influences an individual to think, act etc. Earlier days anthropologists studied the culture of people and society to know the impact of it on group activities. Recent day's studies in culture are not limited to anthropology; it is extended to various subjects like psychology, sociology, organizational behavior etc. Thus it became one of

\footnotetext{
${ }^{1}$ Research Scholar, Department of Psychology, University of Calicut, Calicut University (P.O), Kerala

${ }^{2}$ Associate Professor, Department of Psychology, University of Calicut, Calicut University (P.O), Kerala *Responding Author

(C) 2016 I Sarath p, Manikandan K; licensee IJIP. This is an Open Access Research distributed under the terms of the Creative Commons Attribution License (http://creativecommons.org/licenses/by/2.0), which permits unrestricted use, distribution, and reproduction in any Medium, provided the original work is properly cited.
} 
the important topics in the areas of study which is related with group activities especially in organizational sector. Deal and Kennady (1982) defined culture in the organization as "the way we do things around here." Smith, Farmer and Yellowley (2012) stated that Organizational Culture is the shared values, norms and behaviors that guide how employees work within organization and act as a cohesive group. Culture exists in every organization and influences the performance of the individual and influences group performances. Therefore it is important to study the factors related with culture in this continually changing environment.

Stress is the dynamic condition in which an individual is confronted with an opportunity, constraint or demand related to what he/she desires and for which the outcome is perceived to be both uncertain and important (Robbins, 1999). As the definition states some outcomes are uncertain, the individual have to work to achieve success by overcoming all the challenges, because it is important to him. Sometimes, this will motivate the individual, but some time it may go worst. Just like everyone, individuals working in an organization also facing stress which increase or decrease his performance. Here it becomes important to study and different factors associated with stress in the work place.

Culture of the organization and the stress which arises from working condition are two important factors which largely influence the performance of any employee in a working organization. Both the factors influence the individual in an organization separately or may act together. Therefore, it is also important to find out the hidden relationship between organizational or individual factors with above said factors. It is also important to pull out the relationship between culture and stress in the banks to boost the performance the organization. There are different studies which tried to uncover the relationships. There exist studies which tried to know the relationship between various demographic and organizational variable, of bank employees (Shoaib, Zainab, Maqsood, \& Sana, 2013) There also exist studies which are related with demographic variables and work stress of bank employees (Ayyappan \& Vadivel, 2013; Kumar \& Sundaram, 2014). Samuel (2015) suggests that researchers have to pay keen attention to the relationship between organizational culture and work stress.

Banking sector is one of the major sectors which influence Indian economy. It helped Indian economy to grow up as well as helped the government to expand various services to the people. To grow faster and to extend the hands to the people, country have to boost the performance of the banks in India. Therefore it is important to study various psychological factors which influence the performance of the banks. Without any doubt, anyone can say that, human performances are the backbone of success of any organization. Hence, it can be assumed that employee who is working in the banks have a greater role in predicting the performance of banks. Here comes the importance of studying the various factors which influences the performance of the employees of the banking sector. Among different important variables, organizational culture and work stress are the most important and researched area in the field of banking sector. By studying above said variables and through the results, authorities can 
understand more about organizational culture and work stress. This study is significant in uncovering the relationship between demographic variables, organizational culture and work stress. This study may also bring knowledge of changing nature of the bank employees; the importance of psychological variables in the work place and the importance of intervention or training needs of the employees. The result will be significant to Indian economy as it will enhance the productivity of the Indian bank employees and the organization.

\section{OBJECTIVE}

1. To find out the Main and interaction effect of Organizational culture, types of bank and education on Work stress of bank employees.

\section{Hypothesis}

1. There will be significant Main and interaction effect of organizational culture, types of bank and education on work stress of bank employees.

\section{METHOD}

\section{Participants}

The participants for this study consist of 200 employees belonging to the different Banks situated in Northern Kerala, India. The categorization of the bank was nationalized banks $(\mathrm{N}=68,33 \%)$, cooperative banks $(\mathrm{N}=91,45.5 \%)$ and private banks $(\mathrm{N}=41,20.5 \%)$. The participants were also grouped into two on basis of their education level. The group I ( $N=90,45 \%)$ consist of participants who cleared educational qualification post graduate and above. Degree holders and below the degree were grouped in II ( $\mathrm{N}=110$, 55\%).

\section{Instruments}

1. Organizational Culture Inventory (OCI): Organizational Culture Inventory (OCI) is a 39-item instrument developed by George and Jayan (2010) which is designed to understand an organization's culture and identify the ways to deal with culture-based problems. It also assesses the values and beliefs that help or hinder organizational performance. The reliability coefficient of the organizational culture inventory is 0.802 . The content validity score of organizational culture inventory is 0.945

2. Work Stress Scale: Work stress experienced by the individuals was measured by Work Stress Scale developed by Sarath and Manikandan (2016). This scale measures Control, Demand, Support and Role dimensions of work stress. The total of these dimension constitute the overall work stress of the person concerned. The reliability of the scale was established by calculating Cronbach Alpha of each dimension and the whole scale. Reliability ranges from .53 to .86 and for the total scale it was found to be .60 . The authors of the scale claims that the scale has face validity.

3. Background Information Schedule: The information related to the participants Organization, age, experience, designation, income, education etc. were collected through background information schedule.

\section{Procedure}

The two instruments (Organizational Culture Inventory \& Work stress Scale) along with Background Information Schedule were given to the participants after getting sanction from the 
Managers and personal consent from each participant. Then the investigators explained the purpose and objectives of the study and also clarified their doubts even though the instructions were written on the top of the instruments. After responding to the instruments, it was collected back and checked for omissions and errors, and then the data was fed into a spread sheet for further statistical analysis.

\section{RESULTS AND DISCUSSION}

Banking sector is one of the major sectors in the country which has a great contribution towards the growth of Indian economy. Each bank in the country has its own developmental history, service standards and organizational culture. The major objective of the present study was to find out whether the type of bank and its culture with employees educational qualification has any importance in determining the work stress of banking personnel's.

To know the influence of Organizational culture, types of banks and educational qualification on work stress and its dimensions, the three way ANOVA $(2 \times 3 \times 2)$ was carried out. In this context, it may worth to note that the variable organizational culture was measured in interval scale and the same was classified into two level as poor and good culture based on median score (164) as cut off point. And this yielded good and poor culture. The results of the analysis are presented in the table 1.

Table 1, F values of Control, Demand, Support, Role and Overall Work Stress by Organizational culture, Bank and Education (2x3x3)

\begin{tabular}{|l|c|c|c|c|c|}
\hline \multirow{2}{*}{\multicolumn{1}{c|}{ Source of Variance }} & \multicolumn{5}{c|}{ F values } \\
\cline { 2 - 6 } & Control & Demand & Support & Role & $\begin{array}{c}\text { Overall Work } \\
\text { Stress }\end{array}$ \\
\hline Organizational Culture & 1.06 & 1.06 & 5.85 & 0.06 & 0.43 \\
\hline Bank & 0.16 & $9.40^{* *}$ & $14.59 * *$ & $15.33^{* *}$ & $8.00^{* *}$ \\
\hline Education & 1.06 & 0.25 & $10.03^{*}$ & 0.21 & 2.13 \\
\hline Organizational Culture * Bank & $3.21^{*}$ & 1.54 & $8.80^{* *}$ & $5.98^{*}$ & $6.87 * *$ \\
\hline $\begin{array}{l}\text { Organizational Culture * } \\
\text { Education }\end{array}$ & 0.97 & 0.01 & 0.08 & 5.74 & 1.72 \\
\hline Bank * Education & 0.36 & 2.03 & 0.22 & $4.77 *$ & 2.67 \\
\hline $\begin{array}{l}\text { Organizational culture * Bank * } \\
\text { Education }\end{array}$ & 0.05 & 1.32 & $15.45^{* *}$ & 0.79 & 0.02 \\
\hline
\end{tabular}

${ }^{* *} \mathrm{p}<.01,{ }^{*} \mathrm{p}<.05$

Table 1 gives the results of analysis of variance on overall work stress and its dimensions by organizational culture, type of bank and educational status of banking employees. The table gives the three-way ANOVA, which explains the influence of organizational culture, types of 
banks and educational qualification of banking employees on over all work stress and its dimensions such as control, demand, support and role. The results revealed that, the interactions between organizational culture, types of bank and educational qualification of banking employees does not shows any significant effect on over overall work stress and its dimensions demand, control and role except support $(\mathrm{F}=15.45, \mathrm{p}<.01)$. Support means the encouragement, sponsorship and resources provided by the organization to the individual working for and the support from peers and line managers (Palmer, Cooper \& Thomas, 2001). Here it can be seen that, these three independent variables has a cross over effect on stress variable- support. The result is significant as it shows how the individual affected by lack of support from the organization. Pearlin (1989) stated that Social support is the perfect and the best-established moderating concept. The sources of social support seem to be important because studies were found that the supervisor support has the largest moderating effect on strain manifestation (House \& Wells, 1978).

The two-way interaction shows the significant influence on overall work stress and its dimensions. The results revealed a significant interaction between type of banks and organizational culture on overall work stress $(F=6.87, \mathrm{p}<.05)$, control $(\mathrm{F}=3.21, \mathrm{p}<.05)$, role $(\mathrm{F}=5.98, \mathrm{p}<.05)$ and support $(\mathrm{F}=8.80, \mathrm{p}<.01)$. When the interaction effect of type of bank and educational qualification of the employees, it was found that, the interaction does not have a significant effect on overall work stress and its dimensions except role $(F=4.77, p<.05)$. It was also observed that the interaction effect of educational qualification and organizational culture, little effect was reported. Even though the result does not revealed any direct influence of organizational culture on work stress of the employees, it creates stress when it was interacted with type of bank. But Elenkov and Fileva (2006) stated that organizational culture have great role in job stress. Sumuel (2015) suggested that organizations should make an effort to entrench a culture which will reduce stress level and enhance organizational performance. He also suggested that, though cultural and attitudinal change is difficult to achieve, it is possible to ensure the programmes that will create a culture that reduces employees' stress leading to their commitment in the organization

When the main effect of selected variables considered, it was found that the type of bank has a significant influence on over all work stress $(\mathrm{F}=8.00, \mathrm{p}<.01)$ and its dimensions - demand $(\mathrm{F}=$ 9.40, $\mathrm{p}<.01)$, role $(\mathrm{F}=15.33, \mathrm{p}<.01)$; and support $(\mathrm{F}=14.59, \mathrm{p}<.01)$. From the results, it can interpret that management of the bank has a great impact over employees' performance. Ayyappan and Vadivelu (2013) reported that there is a significant relationship between type of the banks and occupational stress. Malik (2011) found high occupational stress among private bank employees compared to public bank employees. Many researchers also found the influence of type of bank on the stress level of bank employees especially on the stress factor- role (Malik, 2011; Ahmad, Bharadwaj \& Narula, 1985). It is important to note that, there was no significant influence of organizational culture on over overall work stress and its dimensions at any level. But Kanugo (2006), claimed that culture of an organization will influence role conflict and result 
into role stress. Bunnk, Jonge, Ybema and Wolff (1998) indicated that role conflict can occur when expectations and demands are difficult to meet, or are mutually incompatible. In this study organizational culture was just same for the main variable education except on work stress dimension support $(\mathrm{F}=10.03, \mathrm{p}<.05)$.

\section{CONCLUSION}

India is one of the fastest developing countries in the world. The economy in India is highly influenced by the banking system prevails in the nation as it touches and controls every fields that help in the process of development. Here, it is important to analyze different factors which influence the banking sector. The current study explored the work stress of the banking employees in relation with the culture they have in the organization, type of bank they are working in, and the educational qualification of them. The result revealed that, the interactions among organizational culture, types of bank and education does not shows any significant influences on over overall work stress and its dimensions - demand, control and role, except support. Regarding two way interactions, revealed a significant interaction between type of banks and organizational culture on overall work stress, control, role and support. The interaction effect of type of bank and educational qualification of the employees, it was found that, no significant effect on overall work stress as well as its dimensions except role. It also revealed that the interaction of educational qualification and organizational culture, little effect was emerged. When the main effect of selected variables considered, it was found that the type of bank has a significant influence over all work stress and its dimensions - demand, role and support. It is important to note that, there was no significant influence of organizational culture on over overall work stress and its dimensions at any level. The result for education qualification was just as organizational culture except to work stress dimension. The results will be crucial for future researches in the area of banking sector as it gives a new direction in future research.

\section{REFERENCES}

Ahmad, S., Bharadwaj, A., \& Narula, S. (1985). A study of stress among executives. Journal of Personality and Clinical Studies, 1(1), 47-50.

Ayyappan., \& Vadivel, S. (2013). The Impacts of Occupational Stress of Selected Banking Sector Employees in Tamilnadu. International Journal of Finance \& Banking Studies, 2(2), 100-108.

Bunnk, B., Jonge, J., Ybema, J, F., \& Wolff, C. J. (1998), Psychological Aspects of Occupational Stress. In C. D. Wolff., P. J. D. Drenth, Henk Thierry., \& T. Henk (Eds.). Handbook of Work and Organisational Psychology, (2nd Ed.), Jossey-Bass, San Francisco.

Deal, T. E., \& Kennedy, A. A. (1982). Corporate Culture: The Rites and Rituals of Corporate Life. Addison-Wesley Publishing Company.

Elenkov, D., \& Fileva, T. (2006). Anatomy of a Business failure: Accepting the "Bad Luck" Explanation vs. Practively Learning in International Business. Cross Cultural Management: An international Journal, 13(12), 133-141. 
George, R., \& Jayan, C. (2010). Organizational culture inventory, Department of Psychology, University of Calicut, Kerala.

House, J. S., \& Wells, J. A. (1978). Occupational stress, social support, and health. In A.

Kanugo, R. P. (2006). Cross Culture and Business Practice: Are they coterminous or Cross verging? Cross Cultural management: An international Journal, 13(1), 23-31.

Kumar, G, S., \& Sundaram, D, N. (2014). Prevalence of stress level among Bank employees in urban Puducherry. Indian Psychiatry Journal. 23(1), 15-17.

Malik, N. (2011). A study on occupational stress experienced by private and public banks employees in Quetta City. African Journal of Business Management, 5 (8), 3063-3070.

McLean. G. Black, \& M. Colligan. (Eds.). Reducing occupational stress (pp.8-29). Washington. DC. US Department of Health, Education and Welfare, Public Health Service

Palmer, S., Cooper, C., \& Thomas, K. (2001). Model of organizational stress for use within an occupational health education/promotion or wellbeing programme - A short communication. Health Education Journal, 60(4), 378-380.

Pearlin, L. 1. (1989). The sociological study of stress. Journal of Health \& Social Behavior, 30, 241-256.

Samuel, O. B. (2015). The Effects of Organizational Culture and Stress on Organizational Employee Commitment. Scientific and academic publishing, 5(3), 96-106.

Sarath, P., \& Manikandan, K. (2016). Work Stress Scale, Department of Psychology, University of Calicut, Kerala.

Shoaib, C, A., Zainab, N., Maqsood, H., \& Sana, R. (2013). Impact of Organizational Culture on Organizational Commitment:A Comparative Study of Public and Private Organizations. Research Journal of Recent sciences. 2(5), 15-20.

Smith, P., Farmer, M., \& Yellowley, W. (2012).Organizational Behaviour. Routledge, New York.

How to cite this article: Sarath p, Manikandan K (2016), Organizational Culture and Work Stress among Bank Employees, International Journal of Indian Psychology, Volume 3, Issue 3, No. 6, DIP: 18.01.098/20160303 